\title{
O DIREITO DE “SER": O FUTURO E OS DILEMAS BIOÉTICOS NO DIREITO PENAL
}

\author{
Diéssica Taís Silva
}

\section{Resumo}

O futuro humano torna-se incerto com os avanços científicos na área da genética. $O$ presente artigo busca entender os dilemas bioéticos da possibilidade, algumas já atuais e outras ainda futuras, de selecionar embriões de acordo com o sexo, a saúde, as características físicas, psíquicas e comportamentais, além das pesquisas com os embriões excedentes. Afinal, quais os limites para a intervenção genética? A resposta para tal pergunta conduz a análise dos riscos e da necessidade de regulamentação pelo Direito Penal das práticas ditas eugênicas, observando a distinção entre as positivas (aperfeiçoamento) e negativas (terapêutica).

Palavras-chave: Intervenção genética; Dilemas Bioéticas; Regulamentação penal.

\section{INTRODUÇÃO}

Ao ser conquistado pelo homo sapiens (também chamado de zoopolitiken, homolaborius, faber, axiológico, em evolução, multifacetado e complexo), o planeta Terra sofreu e tem sofrido inúmeras transformações, muitas positivas e outras nem tanto. Isso porque, ao mesmo tempo que esse homem vem empreendendo constantes intervenções no meio ambiente, muitas vezes o flagelando, tem ele, ao longo dos anos, alcançado inúmeros avanços na tecnologia e na ciência, o que muito tem contribuído para o seu bem-estar.

O incansável anseio desse homo sapiens levou-o, inclusive, à descoberta da chamada Engenharia Genética, inaugurando, assim, uma nova era, em que a vida passou a ser fabricada e manipulada dentro de um laboratório, através da duplicação,

\footnotetext{
${ }^{1}$ Estudante de Direito na Universidade Católica de Santos, na qual é monitora de Direito Civil das Obrigações. Integrante do Grupo de Pesquisa "Bioética e Direito Penal”, e aluna do Laboratório de Ciências Criminais de Santos do IBCCrim, em qual é associada. E-mail: diessica_tais@hotmail.com
} vol.08, nº. 01, Rio de Janeiro, 2015. pp. 489-515 
transferência e isolamento de genes, filamentos que definem a característica de cada célula.

Em razão disso, alastrou-se, entre a comunidade científica, a possibilidade de intervenções embrionárias nas fertilizações in vitro, através do chamado DGPI (diagnóstico genético de pré-implantação), para a obtenção de organismos geneticamente melhorados. Tal fato, inclusive, vinculou o DGPI à ideia de técnica direcionada ao aperfeiçoamento da raça humana por meio da seleção genética de embriões e metaforicamente à criação de seres humanos personalizados.

E, se as intervenções embrionárias, por um lado, possibilitam diagnósticos e a elaboração de prognósticos mais eficazes, concomitantemente com a terapia para sanar possíveis defeitos genéticos, o que impactará definitivamente a Medicina e tornará possível um planejamento mais adequado, tanto individual quanto do Poder Público, conforme afirma Barth (2005), por outro, colocam a espécie humana em uma situação de desconforto, implicando em controvérsias na comunidade científica acerca de um possível reducionismo genético da pessoa humana e da vida em si como um objeto do mercado.

Isso porque, de acordo com o mesmo autor, um patrimônio genético manipulado de acordo com preferências de terceiros caracteriza a estipulação de critérios de qualidade a que o embrião deve preencher para participar desse mundo, o que é extremamente questionável.

Se a natureza não cria essas modificações ou não as seleciona naturalmente, pode o homem manipular e alterar a natureza? Os eventuais benefícios justificariam os riscos que podem advir dessa ação humana? ( ...) Ao modificar a constituição genética, os cientistas não estão "brincando de Deus", modificando a criatura que é imagem de Deus? (BARTH 2005).

A presente pesquisa, portanto, não busca definir soluções para os dilemas bioéticos que contornam as intervenções embrionárias, mas apenas analisar as nuances desta problemática. Além do mais, tendo em vista tratar-se de uma realidade cada vez menos remota e de ser esta uma questão cheia de controvérsias, sérios riscos e graves consequências, procura-se verificar a necessidade da ingerência do Direito Penal para regulamentar tais práticas. 
A pesquisa é, assim, de indubitável importância, haja vista o inevitável retrocesso rumo ao qual a humanidade pode estar caminhando.

\section{A MANIPULAÇÃO DO GENOMA HUMANO ATRAVÉS DO DGPI}

Se Aristóteles vivesse hoje, certamente passaria algum tempo num laboratório de Engenharia Genética, pois aqui ele poderia resolver, em parte, a dúvida que tanto o atormentava. Ele não perguntava o que era a vida? A vida, sem dúvida, vem a ser o resultado das informações armazenadas num filamento de DNA [genes]. Mexendo-se nesse filamento mexe-se na vida que resultará daquela célula, mudando-se, portanto, o curso da natureza. (BAXTER, 1981)

A fertilização in vitro, um procedimento de maturação dos gametas masculinos e femininos que "produz" embriões em laboratório, constituindo uma forma de reprodução que substitui o ato sexual na concepção, possibilita o DGPI (diagnóstico genético de pré-implantação), que é um exame genético realizado no embrião que se encontra num estágio de oito células (blastômeros) totipotentes, retirando-se uma célula a partir do terceiro dia, sem prejuízo do seu desenvolvimento, para a devida análise (CORRÊA 2001).

O DGPI surgiu em 1990 e é amplamente pesquisado e discutido. A intenção desse exame é, portanto, evitar qualquer tipo de anomalia de caráter genético e o seu domínio evidencia a possibilidade de selecionar e, ainda, otimizar artificialmente características daquele que está em desenvolvimento.

A identificação de genes para selecionar determinadas características e a possibilidade de copiá-las e até mesmo modificá-las levanta um acalorado debate acerca de um caminho que está sendo construído para a implantação de uma eugenia (PEREIRA, 1998).

\section{Eugenia negativa}

Com a realização do DGPI, a reimplantação na mãe do embrião que teve uma de suas células analisada dependerá do seu resultado e, assim, se ele for portador de qualquer anomalia, certamente será considerado "indigno de uma existência e de um 
desenvolvimento", correndo o sério risco de ser friamente descartado ao invés de ser imediatamente submetido a tratamento.

Veja que o diagnóstico de pré-implantação ou até no período fetal permitirá

tranquilizar os pais com antecedentes de alto risco quanto a que o feto não apresenta ou não apresentará malformação ou enfermidade alguma; permitir o tratamento cirúrgico e medicamentoso do feto para curar ou amenizar os defeitos que possa apresentar; através da terapia fetal, indicar o modo de realizar o parto de acordo com as malformações que apresente o feto; determinar o tratamento que deverá ser seguido após o parto ou no decorrer da vida; adotar a decisão do aborto eugênico; decidir o aborto como método de seleção do sexo, assumir a criança que provavelmente apresentará anomalias ou preparar os trâmites legais para sua adoção por terceiros ou seu ingresso numa instituição para crianças abandonadas (MOTA 1999).

A controvérsia ética não está na terapia embrionária ou fetal, mas na seleção de embriões saudáveis e descarte dos demais. Esta é a tal eugenia negativa, que separa o joio do trigo e que para alguns é relevantemente importante para se evitar qualquer interrupção da gravidez após o diagnóstico pré-natal (HABERMANS, 2010).

Atualmente o DGPI permite selecionar, em países com alta tecnologia, embriões livres de cerca de 300 doenças relacionadas com alguns genes, como a fibrose cística, câncer, hemofilia, e anomalias cromossômicas como a que causa a síndrome de Down (TIRABOSCHI 2009). No Brasil, o DGPI é básico e, portanto, além de possibilitar a seleção do sexo, permite a identificação de apenas sete tipos de má formação genética, conforme divulgado em 2012 pela Revista Superinteressante (COSTA e GARATTONI 2012).

Tudo isso é possível porque, com a conclusão do Projeto Genoma em 2003, houve a decodificação de três bilhões de genes responsáveis pelas características normais e patológicas, existentes nos 46 cromossomos do código genético humano. Entre outros resultados importantes obtidos com o projeto, identificou-se que, 99,9\% da sequência do genoma humano é igual em todas as pessoas, com variações individuais que podem tornar um indivíduo predisposto a doenças e disfunções (U.S. DEPARTMENT OF ENERGY HUMAN GENOME PROGRAM, 2008).

Após isso, mais de 70 mil defeitos genéticos em seres humanos já foram identificados e novos dados são constantemente divulgados. No entanto, é preciso frisar 
que apesar desses avanços, os benefícios do sequenciamento completo do DNA levarão tempo para alcançar a maioria da população, tendo em vista a necessidade de refinamento do conhecimento referente ao sequenciamento e às mutações de cada indivíduo, os altos custos que a personalização nos tratamentos acarreta, e a falta de médicos capacitados (DAVIES, 2011).

Contudo, a possibilidade de intervenção na constituição genética para sanar esses defeitos, sejam eles herdados ou adquiridos, através da terapia gênica, já representa a esperança de milhares de pessoas e é uma espécie de tábua de salvação para a Medicina, que ainda não encontrou a fórmula para a cura de diversas doenças (MENCK e VENTURA, 2007).

Por outro lado, levanta a inquietude e o temor de uma grande parte da comunidade científica diante da frágil segurança da Engenharia Genética em razão das várias possibilidades de uso dos conhecimentos que estão sendo adquiridos por ela. É como afirma Lepargneur (Ética e engenharia genética 1998, 237): "A engenharia genética está sob suspeita porque pode gerar o melhor e o pior".

\section{Eugenia positiva}

Ainda mais assustador que as intervenções genéticas para seleção de embriões saudáveis é a possibilidade de selecionar as suas características. Hoje, com o DGPI, já é possível escolher o sexo do bebê, através da seleção do embrião com gene masculino ou feminino, mas acredita-se que a determinação de características físicas não irá demorar muito para ser viável (COSTA e GARATTONI 2012).

Para se ter ideia, em 2001 foi noticiado que o governo islandês havia alienado o DNA de seu país ao vender a uma empresa de biotecnologia, a deCode Genetics, o direito de pesquisar o código genético de sua população em razão da singularidade que ela apresenta. Acredita-se que o isolamento da Islândia tenha provocado pouca variação no código genético de sua população se comparada com outros países, facilitando a identificação de genes que podem causar doenças, alterados por mutações.

Afirma Ramalho (2001) que o objetivo da deCode, com isso, era vender o resultado dos estudos às grandes companhias farmacêuticas e ele, frisa-se, foi atingido, tanto que, seis anos mais tarde, publicou um estudo com a identificação das sequências 
genéticas que determinam os traços físicos dos islandeses, o que causou forte impacto na comunidade científica.

Tudo, segundo o mesmo autor, foi amparado por lei e em doze anos, contabilizado desde 2001, o governo islandês receberia mais de 11 milhões de dólares em participação nos lucros obtidos pela empresa.

Após isso, um geneticista americano, Jeff Steinberg, decidiu iniciar um programa de seleção estética de embriões em sua clínica. Esta notícia foi, sem dúvida, um alarme para toda a sociedade e o geneticista foi criticado por parte da comunidade científica por corromper o DGPI (GOLDBERG, 2009). Tal fato levou-o a cancelar o programa através da página eletrônica de sua clínica, a Fertility Institutes, dizendo que ele estava sendo suplantado pelo impacto social negativo (MARTINS, 2009).

Assim, a Engenharia Genética vai caminhando e, vez ou outra, são veiculadas notícias com alguma descoberta de alto impacto na sociedade. Recentemente, por exemplo, na Universidade de Tóquio, ratos com alterações genéticas foram produzidos para terem um comportamento diferente diante de gatos e não sentirem medo. Já a Universidade de Johns Hopkins, nos Estados Unidos, produziu ratos duas vezes mais musculosos ao desativar um gene ligado a produção de proteína que limita o crescimento muscular nos animais e humanos (TIRABOSCHI, 2009).

Assim também, pesquisas com modelos animais têm levado a identificação de genes que carrega traços do alcoolismo e dependência química, pois diferente de outros genes, eles não apresentam aversões a tais substâncias. Além disso, de acordo com Zatz (1995), foi identificado, por extenso trabalho na Holanda, que indivíduos com comportamentos agressivo e antissocial tinham uma mutação recessiva de um gene do cromossomo X, que causaria a deficiência da enzima responsável pelo metabolismo de neurotransmissores do cérebro.

Aliás, um reputado professor da Universidade de Oxford, Julian Savulescu, em artigo publicado recentemente na Reader's Digest (apud COSTA, 2012), defende a alteração das leis para possibilitar a criação de seres humanos menos violentos e mais inteligentes, devendo isto ser encarado como uma "obrigação moral" de toda a sociedade.

Portanto, mesmo que, em tese, nada tenha saído do laboratório e os "bebês à la carte" ou "designer babies" seja um projeto em estágio inicial, bastante complexo e vol.08, nº. 01, Rio de Janeiro, 2015. pp. 489-515 494 
ainda dependente de identificação dos genes responsáveis por tais características, tal fato não deixa de ser um problema ético atual, pois os cientistas, angariando cada vez mais adesões aos seus planos experimentais, buscam insaciavelmente conhecer a natureza humana e o seu "sopro genético de vida", como exposto acima.

\section{DISCUSSÕES BIOÉTICAS E JURÍDICAS}

\section{O problema da seleção de características}

O respeito pela dignidade humana é o norte para as decisões que podem afetar o ser humano. Kant já dizia que o ser humano deve ser tratado como um fim em si mesmo e jamais como um meio. O que dizer então, da interferência que se faz no ser do outro? Aliás, como moldar ou definir um outro ser sem lhe retirar a identidade?

De fato, a definição biológica do embrião como um amontoado de células lhe retira o direito de ter identidade. A grande verdade, porém, é que o código genético é capaz de definir a identidade do embrião que, ao entrar em contato com o mundo exterior, se determinará como um o ser humano individualizado e subjetivo.

Sob esse prisma, o embrião possui autonomia (liberdade para dar a si suas próprias leis, conforme estabelece Kant), pois ninguém pode lhe impor uma maneira de se desenvolver e ser. Portanto, o embrião precisa ser tutelado no que pertine aos direitos subjetivos e essenciais ao pleno desenvolvimento, tendo em vista sua natureza essencialmente humana e a necessidade de desenvolver livremente as potencialidades de sua personalidade (ESPOLADOR, 2010).

Conforme enfatiza a Declaração Universal sobre o Genoma Humano e os Direitos Humanos em seu preâmbulo, o genoma humano e a sua diversidade constituem o patrimônio da humanidade e, portanto, não poderá ser objeto de qualquer interpretação de natureza política ou social para ferir a dignidade e reduzir o seu valor, o que ocasionaria a quebra da igualdade em direitos de todos os membros da "família humana". 
Alguns pesquisadores acreditarem que certas discussões são ficções científica (TIRABOSCHI, 2009), como as tratadas nos filmes $\mathrm{O}$ admirável mundo novo e Gattaca. No primeiro, Aldous Huxley descreve uma Londres com pessoas selecionadas por suas características físicas e intelectuais, em que não há doenças, conflitos sociais, família, religião, velhice e insegurança e que a sociedade é dividida em castas, sendo as mais baixas compostas por clones, reponsáveis por todo o trabalho braçal (CAPERUTO et al., 2008). No segundo filme, de Andrew Niccol (1997), há a elite dos seres humanos geneticamente selecionados e "perfeitos" física e intelectualmente contra os "filhos de Deus", os nascidos por método natural e, por isso, consideradores seres inferiores, em uma demonstração viva de discriminação racial relacionada à eugenia, como conclui Pena (2006).

O médico e professor universitário, Sérgio Pena, não acredita na concretização do cenário apresentado nas obras citadas. Parafraseando, ele afirma que o gene não é uma ilha e que, portanto, as qualidades humanas resultam da interação entre genética e ambiente. Esta interação, como bem afirma o professor, "é íntima, complexa e nãolinear" (2006, p. o1).

Apesar dessa realidade biológica, o avanço diário dos estudos vem demonstrando uma possibilidade cada vez mais viva de a comunidade científica, a qualquer momento, conseguir definir o comportamento e até mesmo os atributos psíquicos ou de personalidade, como intelectualidade, simpatia, amabilidade, responsabilidade, espírito de liderança e outros através das descobertas dos genes responsáveis por estas características (ZATZ, 1995).

A possibilidade de selecionar e manipular esses genes diante da inexistência de um controle rígido estabelecerá um grande mercado de fabricação de pessoas e a chamada eugenia positiva.

Segundo Pena (2006, p. 01):

Deveríamos descartar o embrião do genial pintor francês Toulouse-Lautrec porque ele era portador de uma forma autossômica recessiva de nanismo, chamada picnodisostose? Ou eliminar o embrião de Wolfgang Amadeus Mozart porque seu genoma continha genes possivelmente relacionados com um distúrbio de comportamento hoje conhecido como síndrome de Gilles de la Tourette? 
Mozart era um gênio apesar de seu distúrbio de personalidade, ou seria sua genialidade uma faceta desse distúrbio? Beethoven compôs a nona sinfonia apesar de sua surdez ou porque era surdo? Vincent van Gogh pintou o seu maravilhoso Céu estrelado apesar da esquizofrenia ou justamente por causa dela? Como ficaria a criatividade de uma sociedade Gattaca de pequenos burgueses, sadios e contentes em sua mediocridade?

Para o professor, portanto, a seleção de embriões deve ser limitada, ocorrendo apenas em casos de doenças graves e incuráveis que possam comprometer radicalmente a qualidade de vida do indivíduo.

Já para Ronald M. Green, Diretor do Instituto de Ética do Dartmouth College EUA (2007), o ser humano deve assumir a direção da própria evolução. Assim, se a espécie humana puder ser moldada, isto deverá ser feito, como forma de melhorar a qualidade de vida das pessoas e promover a justiça social.

Em desacordo com tal entendimento e dentre as inúmeras críticas à fertilização in vitro e à técnica de DGPI, a Igreja Católica afirma que "a realidade do ser humano, com efeito, ao longo de toda a sua vida, antes e depois do nascimento, não permite afirmar nem uma mudança de natureza nem uma gradualidade de valor moral, porque possui uma plena qualificação antropológica e ética" (LEVADA, 2008, p. o1).

Dentre os inúmeros dilemas que o tema levanta, há a adoção do método de fertilização in vitro com DGPI para perpetuar uma característica comum aos pais, o que gera diversas opiniões (TIRABOSCHI, 2009). O incômodo ético é normal, por exemplo, diante da questão: pais surdos têm o direito de tentar ter filhos surdos pelo DGPI? (FRIAS e BIRCHAL, 2012).

Ocorre que, além de tal fato implicar em inúmeras desvantagens futuras que a pessoa terá que sobrecarregar para satisfazer os pais, voltar-se-ia para a questão da seleção. A incerteza de dificuldade no relacionamento de pais e filhos, porém, é a argumentação usada para rebater tal ideia. O cerne da questão, entretanto, deve ser sempre o seguinte: "as técnicas de reprodução assistida têm o papel de auxiliar na resolução dos problemas de reprodução humana”, como determina a Resolução oo 2013/2013 do Conselho Federal de Medicina (CFM).

Outra questão é a seleção com fim terapêutico de embrião compatível com pessoa já existente. As discussões éticas questionam a instrumentalização do ser humano, o melhor interesse da futura criança, a preocupação com a diversidade 
genética reduzida, a destruição de inúmeros embriões e a desaprovação moral da sociedade. Uma objeção comum é que estas crianças não seriam valorizadas pela sua própria existência, mas sempre em função do outro por quem elas nasceram (SOINI et. al., 2006). Recentemente, a imprensa noticiou o nascimento do primeiro bebê no Brasil selecionado geneticamente no laboratório para que seja saudável e compatível com a irmã, que sofre de talassemia major. O objetivo era transplantar as células-tronco do cordão umbilical da recém-nascida na irmã doente.

Esta prática de seleção está regulamentada pelo Conselho Federal de Medicina, na Resolução já citada:

2: As técnicas de RA também podem ser utilizadas para tipagem do sistema HLA do embrião, com o intuito de seleção de embriões HLA - compatíveis com algum filho(a) do casal já afetado por doença, doença esta que tenha como modalidade de tratamento efetivo o transplante de células - tronco ou de órgãos.

Eudes Quintino não vê nenhum confronto ético em tal procedimento. Segundo ele, não se está prejudicando uma vida em razão da outra, mas apenas evitando a doença em uma (a recém-nascida) e a morte na outra (irmã doente). É racional eliminar a doença que afeta a família, mesmo que não haja um futuro receptor de transplante. Além disso, para o autor, a conduta está na linha da legalidade. De fato, sob esse ângulo, não há nada que proíba, já que a seleção está sendo feito em caráter de eliminação de doença genética na futura criança, conforme Resolução do Conselho Federal de Medicina prevê (JÚNIOR, 2012).

O tão falado pós-humanismo já é sentido na sociedade do século XXI. Cada avanço na ciência retrata os "sinais da passagem do homem para um novo patamar de evolução" (MOURA, 2012). Esse novo patamar é incerto e traz à tona uma série de preocupações à sociedade, que se vê afrontada com um futuro imaginável apenas em ficções científicas. O futuro apresenta duas realidades à humanidade: o progresso ou a degeneração moral e a destruição do próprio homem.

\section{O destino dos embriões in vitro}

Saliente-se, de início, que os embriões e mesmo as células germinais ou zigotos humanos não podem ser objetos da Engenharia Genética no Brasil, constituindo crime tipificado no art. 25 da Lei 11.105/2005. 
A Resolução nº 1.957/2010, revogada em 2013, determinava que a intervenção sobre embriões in vitro não poderia ter outra finalidade que não a de avaliar sua viabilidade ou detectar doenças hereditárias, a fim de trata-las ou impedir que ocorresse sua transmissão. No entanto, para atender as mudanças sociais e as constantes e rápidas evoluções científicas, o Conselho Federal de Medicina publicou em 2013 nova Resolução, já citada acima, permitindo a seleção de embriões não só para evitar doenças ao sexo. Veja:

Item I - 4: As técnicas de RA não podem ser aplicadas com a intenção de selecionar o sexo (presença ou ausência de cromossomo Y) ou qualquer outra característica biológica do futuro filho, exceto quando se trate de evitar doenças ligadas ao sexo do filho que venha a nascer.

Item VI - 1: As técnicas de RA podem ser utilizadas acopladas à seleção de embriões submetidos a diagnóstico de alterações genéticas causadoras de doenças.

2: As técnicas de RA também podem ser utilizadas para tipagem do sistema HLA do embrião, com o intuito de seleção de embriões HLA - compatíveis com algum filho(a) do casal já afetado por doença, doença esta que tenha como modalidade de tratamento efetivo o transplante de células - tronco ou de órgãos.

A seleção de embriões, nestas modalidades, todavia, levanta uma questão ética acerca da necessidade de regulamentação e de um maior controle por parte do Poder Público das clínicas de reprodução assistida, haja vista que a criopreservação de embriões se dará somente quanto aqueles que forem considerados viáveis, tornando incerto o destino dos demais, conforme estabelece o item V, 2, da Resolução do CFM no $2.013 / 2013$.

Salienta-se que, geralmente, a criação de embriões na fertilização in vitro ultrapassa o número transferido para o útero da mulher, ainda mais quando o objetivo da seleção é encontrar embriões compatíveis com algum filho afetado por determinada doença. Desta feita, os embriões não utilizados serão congelados e preservados quando não forem tidos como inviáveis.

Ressalte-se que a definição de inviabilidade dos embriões, ao menos indiretamente, ficou ao alvedrio exclusivo do pesquisador, tornando supérflua a limitação protetora da lei, posto que ela foi relegada a um mero decreto, que nem sequer estabeleceu o destino que eles terão, sob no. 5.591, de 2005, art. 30:

XIII - embriões inviáveis: aqueles com alterações genéticas comprovadas por diagnóstico pré-implantacional, vol.08, nº. 01, Rio de Janeiro, 2015. pp. 489-515 499 
conforme normas específicas estabelecidas pelo Ministério da Saúde, que tiveram seu desenvolvimento interrompido por ausência espontânea de clivagem após período superior a vinte e quatro horas a partir da fertilização in vitro, ou com alterações morfológicas que comprometam o pleno desenvolvimento do embrião;

Aliás, na análise da Lei 11.105/2005 pelo Supremo Tribunal Federal em Ação Direta de Inconstitucionalidade de $\mathrm{n}^{-} \mathbf{3} \cdot 510^{2}$, o Ministro Gilmar Mendes, então Presidente, afirmou que o Legislativo foi pouco cuidadoso ao, junto com tema distinto, a saber, biossegurança de atividades que envolvam organismos geneticamente modificados, tratar de assunto tão complexo como o relacionado à pesquisa e terapia com embriões humanos. Ainda, concluiu que o tema é abordado de forma demasiadamente breve, incauta e despreocupada, contrariando a profundidade do assunto, tão amplamente discutido, divergente e de alto impacto para toda a sociedade.

Assim, os embriões considerados inviáveis ou que tiverem sido congelados há mais de 3 (três) anos por serem excedentes, conforme determina a Lei 11.105/2005, poderão ser redirecionados para pesquisa e terapia com células-tronco. Mas, conforme a Resolução do CFM no 2.013/2013, após 5 (cinco) e não 3 (três) anos, os embriões excedentes serão, necessariamente, descartados ou redirecionados para pesquisas de células-tronco, conforme escolha dos eventuais genitores. A Resolução, portanto, estabelece um prazo maior de criopreservação.

De acordo com o item I, da Resolução do CFM no. 2.013/2013, é imprescindível que haja consentimento esclarecido e informado do casal para o descarte ou redirecionamento dos embriões para pesquisa com células-tronco:

3- O consentimento informado será obrigatório para todos os pacientes submetidos às técnicas de reprodução assistida. Os aspectos médicos envolvendo a totalidade das circunstâncias da aplicação de uma técnica de RA serão detalhadamente expostos, bem como os resultados obtidos naquela unidade de tratamento com a técnica proposta. As informações devem também atingir dados de caráter biológico, jurídico, ético e econômico. O documento de consentimento informado será elaborado em formulário especial e estará completo com a concordância, por

\footnotetext{
2 Atenta-se para o fato que, a ADI 3510 foi julgada improcedente por maioria do Tribunal, contrariamente aos Ministros Menezes Direito, Ricardo Lewandowsk, Eros Grau, Cezar Peluso e o então Presidente, Ministro Gilmar Mendes que, em 29.05.2008, a julgaram parcialmente improcedente em diferentes extensões conforme firmado pelo relator Ministro Ayres Britto. 
escrito, das pessoas a serem submetidas às técnicas de reprodução assistida.

O descarte, sem dúvida nenhuma, coloca os embriões como objeto descartável a mercê da vontade de seus eventuais genitores. Já o redirecionamento dos embriões excedentes para pesquisas de células-tronco ocasiona a destruição daqueles para a retirada destas, mas ao menos tem a possibilidade de sanar ou diminuir males inimagináveis através da medicina regenerativa, com um enorme benefício social.

O correto seria a produção de embriões na quantidade exata ou ao menos suficiente para a fertilização, de modo a evitar o descarte ou a destruição de muitos deles e garantir que não sejam tratados como commodity (CLOTET, 2004). Para isso, a medicina reprodutiva deve alcançar cada vez mais precisão e avançar em tecnologia com o DGPI e na técnica de implantação. Enquanto tal progresso não seja realidade, evidente que o redirecionamento dos embriões excedentes para pesquisa e terapia de células-tronco é o melhor a se fazer.

Uma grande preocupação, no entanto, é o redirecionamento imediato dos embriões excedentes, mas viáveis, para pesquisa e terapia de células-tronco, sem o consentimento dos eventuais genitores ou sem que estes tenham conhecimento desta viabilidade. Isso porque, descobriu-se que as células-tronco mais potentes eram encontradas em embriões com poucos dias de desenvolvimento, que ainda não teriam sido diferenciadas e poderiam se transformar em qualquer tecido de um organismo e regenerar um órgão humano. E como já exposto, a utilização dos embriões para este fim ocasionaria, por consequência, a destruição deles para a retirada das células-tronco (ESPOLADOR, 2010).

Outra preocupação que surge é quanto a um controle de qualidade dos embriões, pautado pelos interesses dos genitores, que poderão, em sua maioria e sem nenhuma preocupação ética, optar pelo descarte dos embriões considerados inviáveis por terem sido detectados com doenças hereditárias (transmitidas aos descendentes) ou genéticas (determinadas pelos genes) (Ibidem).

Veja que o DGPI com o objetivo de selecionar o sexo para evitar doenças poderá levar a muitos enganos ou até mesmo um controle seletivo discricionário e discriminatório infundado. Isso porque, se a mulher, que possui dois cromossomos X, tiver apenas um deles com genes de alguma doença, ela será apenas portadora da 
mesma, não significando, todavia, que ela se manifestará, posto que o cromossomo $\mathrm{X}$ normal anula a manifestação do defeito do outro (CLOTET e GOLDIM, 2004). No homem, no entanto, que possui um cromossomo X e outro Y, bastará a alteração do cromossomo X para ocasionar alguma doença genética, que pode ser a hemofilia, as distrofias musculares, a síndrome do X frágil, entre outras (BADALOTTI, 2004).

Nesse caso, portanto, a seleção em tal hipótese tende a possibilitar descartes desnecessários de embriões saudáveis, já que ser portador de determinada doença não é o mesmo que possuí-la. Assim, estaria se condenando um embrião por ser portador de uma anomalia ou doença, que, muitas vezes, não impossibilitaria o seu pleno desenvolvimento, mesmo após, na forma extrauterina.

Em verdade, o que se questiona é um possível estabelecimento de controle de qualidade dos embriões para mera satisfação do conceito de perfeição dos genitores (ROCHA, 20o8). Tal controle de qualidade pode ser identificado como utilitarismo puro, que é "aquele que aprova ou desaprova qualquer ação, segundo a tendência que tem a aumentar ou a diminuir a felicidade da pessoa cujo interesse está em jogo" (ALBUQUERQUE, 2009). Inegavelmente, o maior interesse, a felicidade que se busca preservar e o desejo que se pretende realizar, é o dos pais.

\section{Os embriões possuem direitos?}

De acordo com Rawls (2008), "os direitos assegurados pela justiça não estão sujeitos à negociação política ou ao cálculo dos interesses sociais”. Isso porque, os direitos sociais só existirão se estiverem edificados sob a áurea dos direitos individuais, conforme afirma Dwokin (Ministro Gilmar Mendes, na ADI no. 3510). No entanto, ainda que tal reflexão seja adotada quanto aos direitos das pessoas já neste mundo, da mesma forma não ocorre com relação ao embrião, cujos direitos são incertos e a discussão acerca dos mesmos totalmente divergente.

Pois bem, o ordenamento jurídico brasileiro, em vista das múltiplas posições, consagrou a teoria natalista, determinando no art. $2^{\circ}$, do Código Civil, Lei 10.406/2002, que a personalidade civil inicia apenas com o nascimento com vida, resguardando, entretanto, os direitos do nascituro desde a concepção. 
Os direitos do nascituro estão assegurados pela Constituição Federal, Código Penal, Código Civil e ECA. Segundo Arnoldo Wald (apud GONÇALVES, 2011), o nascituro possui personalidade condicional, que se torna plena com o nascimento com vida. É na qualidade de spes hominis que o nascituro é tutelado pelo ordenamento jurídico.

Observando o artigo do Código Civil em questão e as atuais técnicas de reprodução assistida, é necessário entender a natureza jurídica do nascituro. De acordo com Silvio Rodrigues (2011), o nascituro é o ser já concebido, mas que ainda se encontra no ventre materno. Assim, como se pode depreender pela definição do doutrinador, o embrião extrauterino, ou seja, ainda não reimplantado no útero materno, possui natureza diversa da do nascituro.

Dessa forma, Turcato (2012) elucida que os embriões intrauterino e extrauterino não são tutelados da mesma forma. Aliás, o embrião extrauterino é colocado à margem do Direito, não lhe sendo aplicado o princípio da isonomia, que resguarda os desiguais e evidencia as vulnerabilidades para suplantá-las.

Shirley Mitacoré e Souza Lima (2005) concluem que o embrião, resultado da fertilização in vitro, possui as mesmas especificações genéticas que um concebido naturalmente. Assim, a proteção jurídica estendida aos embriões já em processo de reimplantação na fertilização in vitro, deve ser repensada, pois o fim único, por essência, de qualquer embrião extrauterino, é o útero materno.

O embrião em desenvolvimento, e neste caso não se questiona se extra ou intrauterino, deve ser devidamente respeitado, pois como afirma Maria Helena Diniz (2000), desde a penetração do óvulo pelo espermatozoide, uma nova vida começa a ser gerada e, a partir desse momento, pode se dizer que o embrião passa a ser titular de um patrimônio genético único.

A legislação norte-americana, sem rodeios, trata o embrião como res, objeto de contrato de transferência de propriedade entre os doadores e receptores. No Brasil, a doação de embriões até é permitida, mas categoricamente o item IV, 1, da Resolução no. 2.013/2013 a proíbe com caráter comercial e, o art. $5^{\circ}$, $§ 3^{\circ}$, da Lei 11.105/2005 tipifica tal 
ato na letra do art. 15 , da Lei $9 \cdot 434 / 1997^{3}$. Portanto, os doadores não poderão transformar a produção de material genético em profissão.

Para dar aos embriões condenados uma oportunidade de nascerem, eles podem ser doados para terceiros sem nenhum caráter lucrativo e de forma anônima. A unidade é que será responsável por escolher os doadores, observando ao máximo a semelhança fenotípica e imunológica, além de possível compatibilidade com a receptora (LUNA, 2007). Está bem pontuado, portanto, que os receptores não poderão escolher, com base nos doadores, os embriões potencialmente com as melhores características.

\section{Acesso às práticas seletivas na fertilização in vitro e problema socioeconomico atual e futuro}

Vistas sob um prisma nacional, as novas práticas de reprodução demandam muitos custos e, por isso, não são acessíveis a toda população brasileira com problemas de fertilidade. Em 2005, o Ministério da Saúde instituiu a Portaria no 426, destinada a ampliar o acesso dos casais às técnicas de infertilidade. No entanto, ela foi suspensa logo depois, para análise dos impactos financeiros que causaria à receita pública. Até o momento, portanto, a Portaria em questão não foi implementada (AGÊNCIA CÂMARA DE NOTÍCIAS, 2012).

Em julho de 2012, a Comissão de Seguridade Social e Família, da Câmara dos Deputados Federais, anunciou uma audiência pública para discutir o acesso das famílias à reprodução assistida, pelo Sistema Único de Saúde (SUS).

Como se vê, o novo alcance, discutido e em parte comprovado pela comunidade científica, das técnicas de reprodução assistida, como a fertilização in vitro e o consequente DGPI, estão restritos á população economicamente mais favorecida. Assim, a possível seleção, principalmente no que diz respeito a características físicas, psíquicas e comportamentais, geraria um conflito social de grandeza inimaginável para o Brasil.

Vistas sob um prisma internacional, as novas práticas de reprodução implicam futuros problemas socioeconômicos, que são perfeitamente identificáveis quando

\footnotetext{
${ }^{3}$ Art. 15. Comprar ou vender tecidos, órgãos ou partes do corpo humano: Pena - reclusão, de três a oito anos, e multa, de 200 a 360 dias-multa.
} 
observado a política econômica internacional dos Estados e o biopoder exercido pelos tecnologicamente desenvolvidos (ARAÚJO, s.d.).

Se a possibilidade de seleção de características, principalmente psíquicas e comportamentais se confirmarem, países que hoje detêm o poder tecnológico e, portanto, da Engenharia Genética e das técnicas de reprodução, poderão formar uma elite superpoderosa com viés de exercer um forte poder na relação com outros países. $O$ que de imediato parece remeter a uma ficção científica, merece, de fato, uma atenção especial e um acautelado debate multidisciplinar, pelos inúmeros avisos e questionamentos da comunidade científica de pesquisas no silêncio realizadas nesse sentido.

Ademais, países como a Índia e a China possuem uma clara preferência pelo sexo masculino. A cultura desses países credita pouco valor á figura da mulher, que é vista na Índia, por exemplo, como uma punição por erros do passado. A política coercitiva de planejamento familiar na China contribui para a utilização de métodos alternativos para se garantir um filho homem que, conforme a tradição é o único herdeiro dos bens de família e possui a responsabilidade de cuidar dos pais na velhice.

O aborto de fetos femininos, o não registro civil das filhas, o infanticídio seletivo e até mesmo, a entrega das filhas aos orfanatos, são práticas que fazem parte do cotidiano dos chineses. E, com isso, há um evidente desequilíbrio na razão homens/mulheres no território chinês e a utilização das técnicas de reprodução existentes para seleção de sexo, evidentemente, só tendem a aumentar esse número (CLOTET e GOLDIM, 2004).

\section{PERSPECTIVAS DE PETER SLOTERDIJK E JÜRGEN HABERMAS}

O livro "Regras para o Parque Humano: uma resposta à carta de Heidegger sobre o Humanismo" (200o), foi fruto de uma palestra de Peter Sloterdijk, que deu origem a um enorme debate público na Alemanha, em 1999. O autor condenou a eugenia realizada no silêncio (PONDÉ 2012) e procurou demonstrar a necessidade do ser humano tornar-se um ser reflexivo e ativo nas questões relacionadas ao futuro da própria humanidade.

De acordo com o filósofo, já é hora de despertar e perceber quão preciso é a definição de "regras éticas e controles sociais para as aplicações tecnológicas já ao 
alcance da engenharia genética, em especial, para as assustadoras possibilidades, já fartamente disponíveis, de seleção pré-natal dos próprios seres humanos".

Conforme expõe Sloterdijk, foi o projeto utópico de Platão em "A República", com a proposta idealizada de uma cidade baseada no bem comum, que deu origem ao projeto eugênico ocidental. A sociedade, pelos lábios de Platão, toma forma pelas mãos de um senhor, um pastor ou um super-humanista, que deve planejar e organizar a criação de exemplares humanos com as características necessárias para a formação de um Estado perfeito, com equilíbrio e harmonia. Segundo ele, não é um Deus, mas o próprio ser humano que regula sua automanutenção nos parques humanos.

O humanismo, diz Sloterdijk, constituiu, durante muito tempo, uma tentativa de criação desse Estado perfeito, de desembrutecimento do ser humano. Todavia, ao tornar o ser humano a medida de todas as coisas (Protágoras), o centro e o motivo de todas as decisões, de todas as ações, ele falhou e, ainda, tem ocasionado inúmeros cânceres sociais com a corrida pelo desenvolvimento econômico e científico em proveito desse homem.

Na perspectiva do autor, em análise à Heidegger, o humanismo fracassou porque colocou toda a sua expectativa no próprio homem, acreditando, por ser ele um animal racional, que sua essência pudesse ser expressa zoologicamente. Todavia, sua essência está no fato de SER no mundo, de só existir como "aquele que guarda o ser". Em razão disso, o verdadeiro humanismo depende de uma sociedade reflexiva e não apenas desembrutecida.

Para Nietzsche, ao contrário de Heidegger, afirma o autor, os homens são esses animais racionais que, diante das incomensuráveis promessas de liberdade da modernidade, representam o mais alto poder para a própria espécie. Assim, a depender das suas decisões, poderão caminhar rumo à sua destruição ou evolução. O futuro do gênero humano dependerá, portanto, de decisões políticas, por isso, a necessidade do que Heidegger chamou de ascese reflexiva, que, em Nietzsche, transformaria os homens de sujeitos passivos a sujeitos ativos na construção do futuro humano.

Pensando nisso, não se pode fechar os olhos para os avanços da engenharia genética, que trouxeram à tona a preocupação com o futuro do gênero humano. A passividade não comporta a sociedade contemporânea, em que a Engenharia Genética avança para o planejamento de características, controle do gênero humano pelo vol.08, nº. 01, Rio de Janeiro, 2015. pp. 489-515 506 
nascimento opcional e a seleção pré-natal, práticas de reprodução que podem tornar realidades.

Relembra-se que durante o Nazismo, inúmeras atrocidades foram cometidas contra a espécie humana em nome da arte do embelezamento da Nação. A partir de então, a necessidade de definir regras para o parque humano tornou-se imprescindível, tendo em vista o desenvolvimento ético e científico e a aproximação, cada vez menos remota, da consumação de fatos que podem levar a uma "eugenia liberal" e uma possível simplificação da vida humana.

No livro "O futuro da natureza humana" (2010), Jürgen Habermas discute o melhor tratamento que os Estados democráticos deveriam dar à pesquisa com embriões e ao DGPI, tendo em vista os questionamentos acerca do status moral da vida humana pré-pessoal. O progresso atual gera um mal estar na sociedade no que pertine a melhor coisa a se fazer diante da possibilidade de intervir no genoma humano para além de fins terapêuticos. A falta de limites para o desenvolvimento da ciência da vida pode produzir fatos que se consumarão e serão e normativamente irrecuperáveis.

Segundo o filósofo, o DGPI é moralmente compreensível em casos de doenças hereditárias graves que não poderiam ser suportadas pela "própria pessoa potencialmente em questão". No entanto, ele pode estabelecer uma espécie de controle de qualidade, instrumentalizando a vida humana e produzindo seres de acordo com as preferências de terceiros.

A eugenia liberal aí, se estabeleceria, pregando uma espécie de shopping in the genetic supermarket ${ }^{4}$, que, por um lado, transformaria a relação entre as gerações em objeto de interesses lucrativos da Engenharia Genética e, por outro, imporia subordinação dos descendentes, quanto ao que se é, aos adultos selecionadores de características.

É certo que o embrião não possui proteção absoluta e incondicional da vida e de sua integridade, como pondera o filósofo e sociólogo. Aliás, é exatamente por isso que é possível se falar em expansão dos direitos de liberdade de reprodução dos pais na intervenção genética. Esse direito, no entanto, reduz o status de uma futura pessoa ao

\footnotetext{
${ }^{4}$ Essa ideia reflete o pensamento liberal americano, de acordo com a comparação realizada por Habermas com os EUA e a Alemanha (2010, 104).
} 
prejudicar a sua consciência de ser autônomo e igual, confundindo-a com um mero objeto.

Com isso, Habermas questiona se "é compatível com a dignidade humana ser gerado mediante ressalva e, somente após um exame genético, ser considerado digno de uma existência e de um desenvolvimento? Podemos dispor livremente da vida humana para fins de seleção?" (2010, 28-29).

Nesse sentido, ele busca identificar os princípios morais que poderiam nortear a política pública em relação às intervenções genéticas. Para tanto, refere-se a imprescindibilidade de entender a real interferência da manipulação genética na autocompreensão do homem enquanto ser da espécie humana, a distinção corrente entre o que cresceu naturalmente e o que foi fabricado, a limitação da configuração autônoma da vida humana e a alteração nas relações entre as pessoas e, por fim, que o direito a uma herança genética não manipulada é tema diferente do aborto.

Habermas conclui que não se pode perder a sensibilidade moral para questionar o custo-benefício dessa transposição de limites, visto que a instrumentalização da vida humana é extremamente assustadora. Aliás, a ponderação deles a tempo possibilitará discussões serenas e decisões mais acertadas.

\section{CONSIDERAÇÕES FINAIS}

O direito há de cuidar da vida do homem com a indisponibilidade que o caracteriza, com a integridade que a assegura, com a liberdade que a humaniza, com a responsabilidade que a possibilita" (Ministra Carmém Lúcia, na ADI no 3.510).

O valor da vida humana é, historicamente, mas principalmente após a Segunda Guerra Mundial, utilizado, como um limite às desenvolturas do ser humano que, por diversas formas, a longo e curto prazo, coloca em risco a própria espécie. Os indivíduos e sociedades não podem ter liberdade completa enquanto a violência perdurar ${ }^{5}$. Ora, o que seria, senão violência, a intervenção não terapêutica no ser do outro?

\footnotetext{
${ }^{5}$ Bertrand Russell: "Enquanto alguns homens quiserem cometer violências contra os outros não pode haver liberdade completa. Por essa razão, por mais que os indivíduos e sociedades devam ter máxima liberdade sobre seus próprios assuntos, eles não podem ter liberdade completa em suas relações com os outros. Dar liberdade aos fortes para que eles oprimam os fracos não é o caminho para garantir que as sociedades do mundo sejam mais livres."
} 
A dignidade da pessoa humana, fundamento da República Federativa do Brasil, confere à vida um valor imprescindível, não absoluto, mas fundamental. É nesse sentido que o Direito Penal, como em uma função ético-social, proíbe qualquer lesão a esse direito. Todavia, os avanços científicos trouxeram à tona uma preocupação com as possibilidades de existência do gênero humano no futuro, levando a comunidade jurídica a repensar os contornos da atuação na sociedade da Engenharia Genética ${ }^{6}$.

Esta preocupação enseja, dessa forma, um novo olhar sobre a humanidade, com limites normativos que possam estabelecer a moderação entre o desenvolvimento técnico-científico e a responsabilidade com a vida humana, tendo em vista seu valor ético e jurídico.

O medo que persiste é a desumanização das técnicas e das consequências de sua utilização para a humanidade. Ao lado da dignidade humana, há que se enfatizar a responsabilidade de todos, uns em relação aos outros e em relação às gerações presentes e futuras, o que determina a busca de equilíbrio na equação liberdade de pesquisa/liberdade individual. (...) Os direitos humanos fortalecem-se, pois, como fator garantidor da humanidade contra a manipulação genética que pode eliminar a individualidade, a singularidade, a diversidade que se consagra na espécie humana e a torna viva, contínua e plural em sua dinâmica (Ministra Carmém Lúcia, na ADI no 3.510 ).

Os direitos não nascem todos de uma vez, segundo Bobbio (2004). Eles nascem com o desenvolvimento da sociedade e a capacidade de dominação do homem sobre o próprio homem. É por isso que o Direito não é só valor ou norma, mas também fato, já dizia Reale (2001). Aí, então, é que entra a necessidade de se garantir a segurança pública.

$\mathrm{Na}$ atual realidade, os avanços científicos e tecnológicos, com a possibilidade de manipulação genética e seleção de embriões, colocam a humanidade num estado de vulnerabilidade e, portanto, em perigo.

Finalmente, o potencial apocalíptico da técnica - sua capacidade para pôr em perigo a sobrevivência do gênero humano ou corromper sua integridade genética, ou alterála arbitrariamente, ou até mesmo destruir as condições de uma vida mais elevada sobre a terra - coloca a questão metafísica, com a qual a ética nunca fora anteriormente

\footnotetext{
${ }^{6}$ De acordo com Noberto Bobbio (2004), surge com esse desenvolvimento técnico-científico uma quarta geração de direitos fundamentais, decorrentes das manipulações do patrimônio genético. vol.08, nº. 01, Rio de Janeiro, 2015. pp. 489-515 
confrontada, qual seja: se e por que deve haver uma humanidade; por que, portanto, o homem deve ser mantido tal como a evolução o produziu; por que deve ser respeitada sua herança genética; sim, por que, em geral, deve haver vida. A pergunta não é ociosa como parece (na ausência de alguém que seriamente negue todos esses imperativos), pois a resposta a ela é significativa acerca do quanto, permitidamente, nos é lícito arriscar em nossas grandes apostas tecnológicas e quais riscos são inteiramente inadmissíveis. Se existir é um imperativo categórico para a humanidade, então todo jogo suicida com essa existência está categoricamente proibido, e ousadias técnicas, nas quais esta é a aposta, ainda que apenas remotíssima, devem ser desde o início excluídas. (JÚNIOR, 1999).

Como bem estabelece Hans Jonas (2006), todas as éticas tradicionais não são capazes de orientar essa nova realidade e, por isso, ela deve ser orientada para o futuro, de forma a proteger as gerações vindouras das consequências das ações humanas presentes. Esta é a ética da responsabilidade, que deve, em conformidade com a máxima "não ponhas em perigo as condições de continuidade indefinida da humanidade na Terra", servir de norte para o Direito.

Sabe-se que o futuro é imprevisível, pois não se sabe ao certo até onde o homem irá chegar (SILVEIRA, 2010). Por isso mesmo, é tão necessário tornar efetivo o princípio consagrado por Hans Jonas: PRINCÍPIO DA RESPONSABILIDADE.

Desta feita, o Direito é chamado justamente para dar efetividade a esse princípio. Para tanto, o jus puniendi deve ser ativado com relação a tais questões, impondo limites e orientando condutas de acordo com um "mínimo ético".

O Direito Penal, como se sabe, tutela de forma eminentemente efetiva os bens jurídicos mais relevantes da sociedade. Ora, a integridade genética deve ser digna de proteção no ordenamento jurídico, de forma a impor limites jurídicos à seleção de embriões e à pesquisa com os mesmos. O problema é que o Direito Penal está imerso em um dilema ${ }^{7}$ : "manter-se fiel ao paradigma do Iluminismo ou expandir-se e reformular-se para fazer face às ameaças da sociedade pós-industrial" (MINAHIM apud PESSOA, 2007).

\footnotetext{
${ }^{7}$ Diferentemente de outros países, como os europeus, o país não possui lei específica para regular com precisão a seleção de embriões e a pesquisa com os mesmos. O Conselho da Europa recomendou aos seus Estados-membros a proibição da seleção de sexo não terapêutica. Países como a Alemanha e Noruega, por exemplo, proíbem penalmente esse tipo de prática. (SOUZA 2004)
} vol.08, nº. 01, Rio de Janeiro, 2015. pp. 489-515 
O mundo jurídico deve acompanhar com cautela os desafios desse "admirável novo mundo" que se aproxima, até porque, como bem colocado por Maria A. Minahim (IBIDEM), as questões que envolvem a seleção e a manipulação genética são achados científicos provisórios e muitos, ainda, incertos.

Apesar disso, é preciso uma orientação responsável do Direito, que deve, de modo preventivo, evitar que certas possibilidades venham a se consumar.

\title{
THE RIGHT TO "BE": THE FUTURE AND THE DILEMMA BIOETHIC IN
} CRIMINAL LAW

\begin{abstract}
The human future becomes uncertain with scientific advances in genetics. This article seeks to understand the possibility of bioethical dilemmas, some already present and others still to come, to select embryos according to sex, health, physical, psychological and behavioral, in addition to research on surplus embryos. After all, what are the limits to genetic intervention? The answer to this question leads to analysis of risks and the need for regulation by the Criminal Law of eugenic practices said, noting the distinction between positive (improvement) and negative (therapeutic).
\end{abstract}

Keywords: Genetic intervention; Bioethical dilemmas; Criminal regulation.

\section{REFERÊNCIAS BIBLIOGRÁFICAS}

AGÊNCIA CÂMARA DE NOTÍCIAS. Comissão discute acesso das famílias à reprodução assistida pelo SUS. 10 de Jul. de 2012. Disponível em: <http://www2.camara.gov.br/agencia/noticias/SAUDE/421967-COMISSAODISCUTIRA-ACESSO-DAS-FAMILIAS-A-REPRODUCAO-ASSISTIDA-PELOSUS.html>. Acesso em: 2012.

ALBUQUERQUE, Antonio Armando Ulian do Lago. Introdução a teoria do Direito do Direito de Ronald Dworkin. [s.l.: s.n.], 2009, pp. 01-42.

ARAÚJO, Inês Lacerda. Foucault, formação de saber, o poder disciplinar e o biopoder enquanto noções revolucionárias. Revista Itaca, s.d., pp. 11-29.

BARTH, Wilmar Luiz. Engenharia Genética e Bioética. Portal de Periódicos da PUCRS, Set. de 2005, pp. 361-391. 
BETSCH, David F. DNA Fingerprinting in human healthand society. Nov. de 1994. Disponível em: <http://www.biotech.iastate.edu/biotech_info_series/bio6.html>. Acesso em: 2012.

BOBBIO, Noberto. A era dos direitos. [s.l.]: Campus, 2004.

CAMARGO, Erney F. Plessmann de. A biologia molecular na USP. Estudos Avançados - Universidade de São Paulo, 1988, pp. 93-97.

CANDEIAS, José Alberto Neves. A Engenharia Genética. Revista Saúde Pública, 1991, pp. 03-10.

CAPERUTO, Ada, et al. Admirável Mundo Novo: Uma Perspectiva Histórica entre a Obra e a Sociedade Pós-Moderna. Biblioteca Online de Ciências da Comunicação, 2008, pp. o1-10. Arquitetura da Destruição. Direção: Peter COHEN. 1992.

CORRÊA, Marilena Villela. Novas tecnologias reprodutivas: limites da biologia ou biologia sem limites? Rio de Janeiro: EdUERJ, 2001.

COSTA, Alexandre. Engenharia genética de bebés é uma "obrigação moral". Expresso - Portugal, 2012.

COSTA, Camilla; GARATTONI, Bruno. Como fazer super bebês. Revista Superinteressante, Fev. 2012.

DALlARI, Dalmo de Abreu. Bioética e Direitos Humanos. s.d. Disponível em: $<$ http://www.portalmedico.org.br/biblioteca_virtual/bioetica/ParteIIIdireitoshumanos. htm.>.

DAVIES, Kevin. Mapear genoma será tão rotineiro quanto exame de raio-X. 23 de Out. de 2011. Disponível em: <http://veja.abril.com.br/noticia/ciencia/seu-genoma-por1-ooo-dolares\#genoma>. Acesso em: 2012.

DINIZ, Maria Helena. O estado atual do Biodireito. São Paulo: Saraiva, 2000.

DIZER O DIREITO. Decisão do STF na ADPF 54: não existe crime de aborto de fetos anencéfalos. Abr. de 2012. Disponível em: <http://www.dizerodireito.com.br>. Acesso em Set. de 2012.

ESPOLADOR, Rita de Cássia Resquetti Tarifa. Manipulação genética humana: o controle jurídico da utilização de embriões em pesquisas científicas. Tese apresentada sob orientação do Prof. Dr. Eduardo de Oliveira Leite para obtenção de grau de Doutror em Direito das Relações Sociais. Curitiba, 2010.

FRIAS, Lincoln; BIRCHAL, Telma. Pais surdos têm o direito de ter filhos surdos? Revista Opinião Filosófica, 2012, pp. 05-13. 
GETOR/GGSTO/GADIP/ANVISA. Nota Técnica n. ${ }^{\circ}$ ooz/2o11. In: Ações de Vigilância Sanitária em Reprodução Humana Assistida. 27 de Maio de 2011.

GOLDBERG, Allen. Select a baby's health, not eye color. Los Angeles Times, Feb. de 2009.

GONÇALVES, Carlos Roberto. Direito Civil Brasileiro - Volume 1. São Paulo: Saraiva, 2011.

GREEN, Ronald M. Babies By Design: the Ethics of Genetic Choice. Yale University Press , 2007.

HABERMAS, Jürgen. O futuro da natureza humana. São Paulo: WMF Martins Fontes, 2010.

INSTITUTO DE TECNOLOGIA ORT. O Que é Biotecnologia? 23 de Dez. de 2011. Disponível em: <http://www.ort.org.br/biotecnologia>. Acesso em: 2012.

JONAS, Hans. O Princípio Responsabilidade: Ensaio de uma Ética para a civilização tecnológica. Tradução: Marijane Lisboa e Luiz Barros Mantez. Rio de Janeiro: Contraponto/ PUC-RIO, 2006.

JÚNIOR, Eudes Quintino de Oliveira. Você geraria um filho para salvar outro? Migalhas, 2012.

JÚNIOR, Oswaldo Giacoia. Hans Jonas: por que a técnica moderna é um objeto para a ética. Natureza Humana, 1999, pp. 407-420.

LEPARGNEUR, Hubert. Ética e engenharia genética. O mundo da Saúde, 1998, p. 237.

LEVADA, William Card. Instrução Dignitas Personae sobre algumas questões de Bioética. Congregação para a Doutrina da Fé, Vaticano, 2008.

SOUZA, Shirley Mitacoré de Souza; LIMA, Souza. Tratamento jurídico do embrião. Revista Jus Navigandi, 2005.

LUNA, Naara. A personalização do embrião humano: da transcedência na Biologia. Mana: Estudos de Antropologia Social, 2007, pp. 411-440.

MARQUES, José Oscar de Almeida. Sobre as regras para o parque humano de Sloterdijk. Revista Internacional de Filosofia e Práticas Psicoterápicas, 2002, pp. 363381.

MARTINS, Paula Pedro. Clínica oferecia escolha de características físicas dos bebés. ALERT Life Sciences Computing, 2009. 
MENCK, Carlos Frederico Martins; VENTURA, Armando Morais. Manipulando genes em busca de cura: o futuro da terapia gênica. Revista USP, no 75, 2007, pp. 50-61.

MOTA, Sílvia. Da bioética ao biodireito: a tutela da vida no âmbito do Direito Civil. Dissertação do programa de Mestrado em Direito Civil na Universidade do Estado do Rio de Janeiro, 1999.

MOURA, Matheus. Da ficção ao real. s.d. Disponível em: $<$ http://filosofia.uol.com.br/filosofia/ideologia-sabedoria/27/artigo191871-1.asp>. Acesso em: 2012.

GATTACA. Direção: Andrew NICCOL. 1997.

PENA, Sergio Danilo. Bebês à la carte? Instituto Ciência Hoje, 2006.

PEREIRA, Gonçalo. As células do bem e do mal. 10 de Jun. de 1998. Disponível em: http://veja.abril.com.br/100698/p_o4o.html. Acesso em: 2012.

PESSOA, Flávia Moreira Guimarães. Biotecnologia e Direito Penal: o bem jurídico tutelado pelo art. 24 da Lei de Biossegurança. Boletim Jurídico, 2007.

PONDÉ, Luis Felipe. A palavra feia. São Paulo: Folha de São Paulo, Abr. 2012.

RAMALHO, Élcio. O país que vendeu o DNA de seu povo. Revista VEJA, no 1694, Abr. 2001.

RAWLS, John B. Uma teoria da justiça. Martins Fontes, 2008.

REDE EDUCACIONAL DO GRUPO VIRTUOUS. Os conceitos de fenótipo e genótipo. s.d. Disponíel em: $<$ http://www.sobiologia.com.br/conteudos/Genetica/leismendel4.php>. Acesso em: Set. de 2012.

ROCHA, Renata da. O Direito à vida e a pesquisa com células-tronco: limites éticos e jurídicos. Rio de Janeiro: Elsevier, 2008.

RUSSELL, Bertrand. Os ideais da política. Revista VEJA, 1943.

SILVEIRA, Denis Coitinho. Uma análise do Princípio de Responsabilidade de Hans Jonas: suas implicações metaéticas. [s.l.]: ETHICA, 2010, pp. 137-151.

SLOTERDIJK, Peter. As regras para o parque humano: uma resposta à carta de Heidegger sobre o humanismo. São Paulo: Estação Liberdade, 2000.

SOINI, S., et al. The interface between assisted reproductive technologies and genetics: technical, social, ethical and legal issues. European Journal of Human Genetics, 2006, pp. 588-645. 
SOUZA, Paulo Vinicius Sporleder de. Seleção de sexo: aspectos jurídico-penais.” In: CLOTET, Joaquim; GOLDIM, José Roberto, Seleção de sexo e Bioética, Porto Alegre: EDIPUCRS, 2004, pp. 73-82.

TIRABOSCHI, Juliana. Crianças sob medida. Revista Galileu, no 211, 2009.

TURCATO, Lilian Renata de Almeida. Os limites à manipulação genética na eliminação dos embriões excedentes. Monografia para obtenção de título de pósgraduação em Direito Constitucional, sob orientação da Profá. Dra. Gisele Mendes de Carvalho. Maringá, 2012.

U.S. DEPARTMENT OF ENERGY HUMAN GENOME PROGRAM. Insights from the Human DNA Sequence. Jun. de 2008. Disponível em: <http://www.ornl.gov/sci/techresources/Human_Genome/publicat/primer20o1/index.s html>. Acesso em: 2012.

VEJA. As fábricas de vida. o2 de Set. de 1981. Disponível em: $<$ http://veja.abril.com.br/arquivo_veja/capa_02091981.shtml>. Acesso em: 2012. ZATZ, Mayana. Comportamento e genes: genético é diferente de hereditário. 2007. 27.

Os dilemas éticos do mapeamento genético. Revista USP, 1994/ 1995, pp. 20-

Trabalho enviado em 31 de agosto de 2014.

Aceito em 31 de janeiro de 2015. 